\title{
The Influence of the Role of Halal Tourist Destinations on Interest in Visiting
}

\author{
Putu Nina Madiawati ${ }^{*}$, Sulistijono² and Jella Zumalia Fitri ${ }^{3}$ \\ 1 Telkom University, Jalan Terusan Buah Batu, Bandung, 40257, Indonesia; pninamad@telkomuniversity.ac.id \\ 2 Telkom University, Jalan Terusan Buah Batu, Bandung, 40257, Indonesia; listijo58@telkomuniversity.ac.id \\ 3 Telkom University, Jalan Terusan Buah Batu, Bandung, 40257, Indonesia; jellazumaliafitri9@gmail.com \\ * Correspondence: pninamad@telkomuniversity.ac.id
}

Received: 2021-02-11; Accepted: 2021-04-07; Published: 2021-05-25

\begin{abstract}
The purpose of this study was to determine how big the role of the image of halal tourist destinations on visiting interest is influenced by market potential, electronic word of mouth (E-WOM), and social media. The research method uses quantitative methods, with data processing using SEMPLS (Partial Least Square). The results showed that the role of halal tourist destinations on visiting interest has a big influence. The image of halal tourist destinations will not develop properly if it is not supported by E-WOM, social media, and market potential, which are carried out continuously. Therefore, good cooperation between the local government, the community and all related parties are required to increase halal tourism.
\end{abstract}

Keywords: Elektronic Word of Mouth ; Halal tourist destinations; Influence; Interest in Visiting.

\begin{abstract}
Abstrak: Tujuan dari penelitian ini adalah untuk mengetahui seberapa besar peran image destinasi wisata halal terhadap minat berkunjung yang dipengaruhi oleh potensial pasar, electronic word of mouth (E-WOM), dan media sosial. Metode penelitian menggunakan metode kuantitatif, dengan pengolahan datanya menggunakan SEM-PLS (Partial Least Square). Hasil penelitian menunjukkan bahwa peran destinasi wisata halal terhadap minat berkunjung memiliki pengaruh besar. Citra destinasi wisata halal tidak akan berkembang dengan baik jika tidak didukung oleh E-WOM, media sosial, dan potensi pasar yang dilakukan secara terus menerus. Oleh sebab itu maka diperlukan kerjasama yang baik antara pemerintah daerah, masyarakat dan semua pihak yang terkait dilingkungan setempat untuk dapat berkerjasama guna meningkatkan pariwisata halal.
\end{abstract}

Kata Kunci: Destinasi wisata Halal; Elektronic Word of Mouth; minat berkunjung; Pengaruh.

\section{Introduction}

The existence of halal tourist destinations is a necessity amid the dynamics of the tourism sector's development (Imran \& Efendi, 2016). The terminology of tourism in the Islamic context is permissible as long as it does not go outside the rules established by Allah SWT (Pradana, Huertas-García, \& Marimon, 2020). The basis of tourism according to Islam must be based on the Al-Quran and Hadith. A strong foothold on Al-Quran and Hadith will significantly impact the growth and development of world halal tourism, especially in Indonesia (Fatkurrohman, 2017).

Safar or a tour to contemplate Allah Ta'la's creation, to enjoy the beauty of the extraordinary nature as an incentive for the human soul to strengthen faith in the oneness of Allah and motivate fulfillment of life obligations as mentioned by Allah in surah Al-Ankabut verse 20 by Imam Iskender Ali Mihr, "Travel in the earth and see how the first creation was. Then Allah will build (fulfill) the Creation of the Hereafter. Surely Allah has Power over all things."

When Allah mentions "walk or travel on earth", Allah reminds us of nature, natural tourism. Many things in nature can be used as tourist objects because Allah created nature with various characteristics.

Dusun Sebalang, Tarahan Village, is a protected area in South Lampung Regency, which has a mangrove forest covering an area of 5 ha and is overgrown with mangroves. In 2017, the Role of Local Government in Managing Mangrove Forests in Sebalang Hamlet had become a modern tourist attraction that can attract visitors to come. Sebalang Mangrove Forest has many photo spots that attract 
visitors; besides, there are also cafes and places of worship, where tourist visitors relax enjoying nature and don't forget their worship.

Visiting interest in Marketing for Hospitality and Tourism is assumed to be the same as buying interest (P. Kotler \& Keller, 2016). According to Annafik and Rahardjo (2012) visiting intention is the stage where a person forms their choice between several brands and who ultimately will purchase an item or service based on several considerations, one of which is the image of a halal tourist destination. The local government's halal tourism destination program can increase the number of ecotourism visitors to the Sebalang mangrove forest every month, and it is hoped that it can develop into a leading tourist attraction in South Lampung Regency. According to Aaker (2012), image is a unique set of associations that marketers want to create or maintain. Croy (2014) mentions the importance of image for a tourist destination, namely creating hope, can be used as a marketing strategy and market segmentation, is a form of consumption, influences prospective markets, and plays a role in satisfaction and selection destination areas.

However, in reality, halal tourist destinations' image cannot develop quickly if an increase in market potential does not support it (Madiawati \& Pradana, 2016). According to Kotler, et al., (2016), a potential market is a group of consumers who express their interest in a market offer on a particular product or service, for example, a group of tourists interested in coming to a tourist destination. The high potential of the halal tourism market can be seen from the increasing number of tourists. Data compiled by the Global Muslim Travel Index (GMTI) shows that the number of Muslim tourists is estimated to reach 158 million people in 2020. This figure has grown 21 percent compared to the number of tourists in 2017.

Apart from the potential market, the role of electronic word of mouth (E-WOM) and social media is needed to improve halal tourist destinations' image.

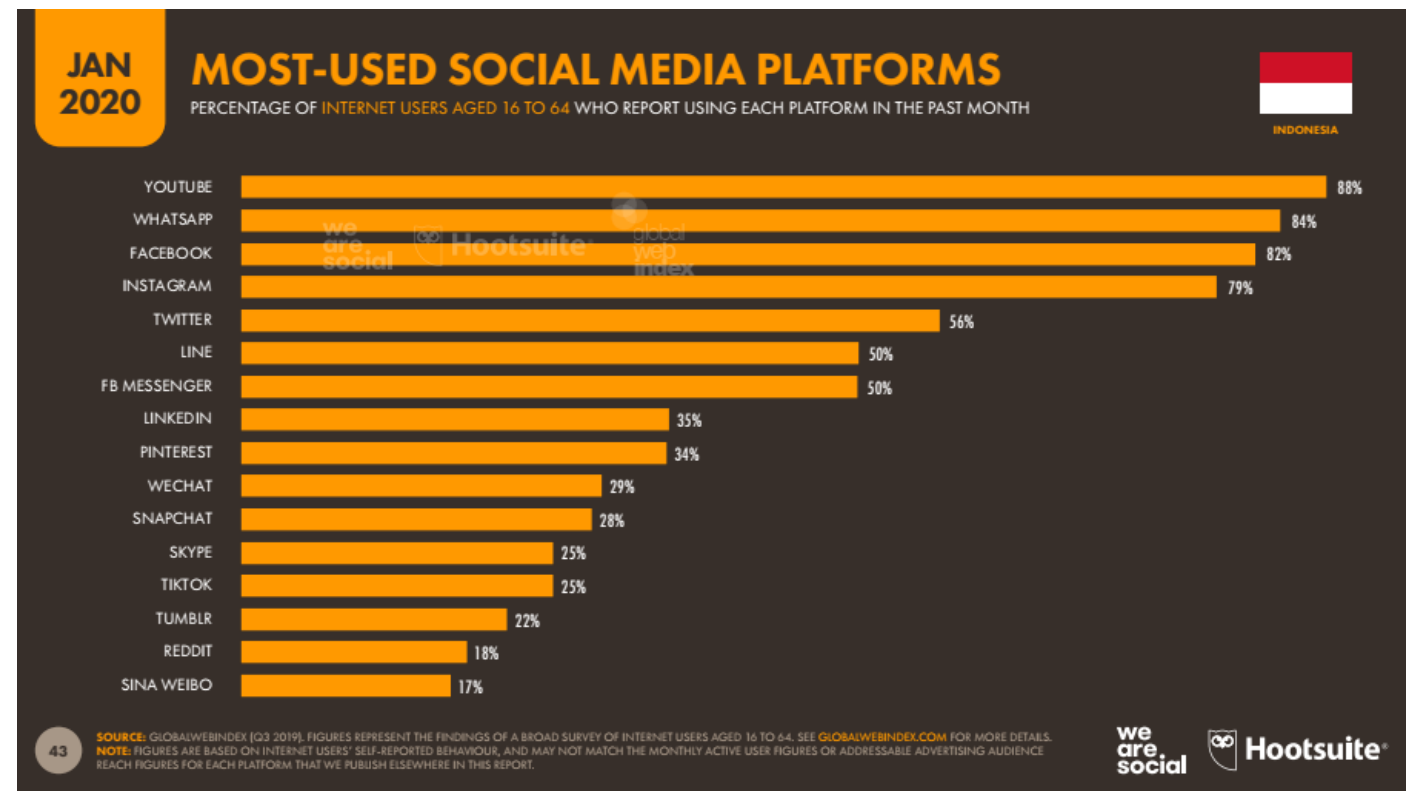

Figure 1. Most-Used Social Media Platforms in Indonesia

Source: https://teknoia.com/data-internet-di-indonesia-dan-perilakunya-880c7bc7cd19

Data from WeareSocial and Hootsuite about Indonesia's digital landscape in 2020, which is shown in Figure 1, shows that how social media in Indonesia has become a fairly dominant service in cyberspace. Social media acts as a means of communication that connects individuals with other individuals or groups, whether they are known or not. Kotler and Keller (2016), social media is a media used by consumers to be based on text, images, sound, and video information, both with other people and companies and vice versa. Meanwhile, according to Jamiat et al. (2020), social media is an internetbased media that allows users to interact and present themselves, either immediately or delayed, with a broad audience or not, which encourages the value of user-generated content and the perception of 
interactions with others. This form of communication is known as electronic word of mouth. Maharani et al. (2016) believe that electronic word of mouth is a very important place for consumers to give their opinion and is considered more effective than word of mouth because of the level of accessibility and reach wider than traditional offline media word of mouth.

Extensive literature review in the field of halal tourism has been done. This topic has been largely discussed using tourism and marketing theories. However, there is stil gap that there has not been many literatures explore te topic from e-communication point of view. Based on this phenomenon, the purpose of this study is to find out how big the role of the image of halal tourist destinations on visiting interest is influenced by potential market, electronic word of mouth (E-WOM), and social media.

\section{Research Methods}

The research method used in this research is quantitative method. The population of this study were tourists who visited the mangrove forest tourism area in Tarah village. with a sample size of 100 respondents. Data processing was done using Partial Least Square (PLS). PLS (Partial Least Square) is a variant-based structural equation analysis (SEM) that can simultaneously test the measurement model as well as test the structural model.

Ghozali (2015) explains that PLS is a soft modeling method of analysis because it does not assume that the data must be measured at a certain scale, which means that the number of samples can be small (under 100 samples). The hypothesis is a temporary answer to the formulation of the research problem (Sugiyono, 2018). It is said temporarily, because the answers given are only based on relevant theories, not based on empirical facts obtained through data collection, while the hypothesis of this study is as follows:

- H1. There is a Potential Market Influence on Destination Image

- H2. There is an Effect of Electronic Word of Mouth on Destination Image

- H3. There is an influence of social media use on Destination Image

- H4. There is an Influence of Destination Image on Visiting Interest

- H5. There is an Influence of Potential Market, Electronic Word of Mouth, and Social Media on Visit Interest Through Destination Image.

The research model used in this study is shown in figure 2 .

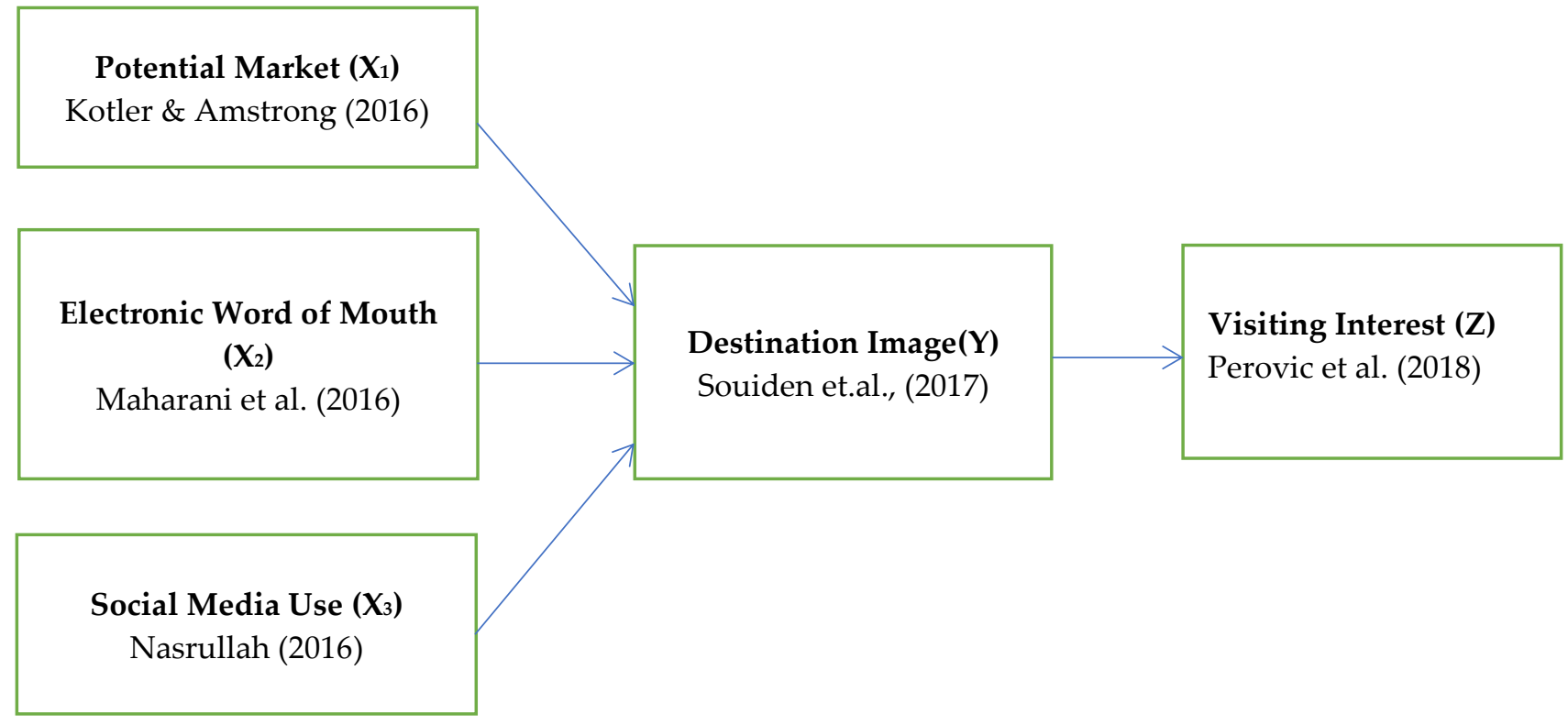

Figure 2. Research Model

Source: Author's Own Elaboration (2021) 


\section{Result and Discussion}

We spread the questionnaire to 100 respondents. We used purposive sampling in determining the respondents and we chose the criteria as tourists who have experienced halal tourism. The questionnaire was distributed online to around 140 respondents, and in the end, we concluded 100 valid replies.

The profiles of respondents are almost equal between male and female respondents, which are $43 \%$ and $57 \%$. In the age group, we gathered more young tourists (21-25 years), which are $49 \%$ of our total respondents. Since tourism is a popular activity among young respondents, we also found that most of our respondents are university students (51\%). Following table 1 are the demographic characteristics of the respondents:

Table 1. Demographic Characteristics

\begin{tabular}{|c|c|c|}
\hline Question & Item & Percentage \\
\hline \multirow[t]{3}{*}{ Gender } & Male & $43 \%$ \\
\hline & Female & $57 \%$ \\
\hline & Total & $100 \%$ \\
\hline \multirow[t]{6}{*}{ Age } & $15-20$ years & $28 \%$ \\
\hline & $21-25$ years & $49 \%$ \\
\hline & $26-30$ years & $12 \%$ \\
\hline & 31 - 35 years & $2 \%$ \\
\hline & $>36$ years & $9 \%$ \\
\hline & Total & $100 \%$ \\
\hline \multirow[t]{5}{*}{ Profession } & Student & $51 \%$ \\
\hline & General Employees & $21 \%$ \\
\hline & Housewife & $9 \%$ \\
\hline & Other & $19 \%$ \\
\hline & Total & $100 \%$ \\
\hline
\end{tabular}

Source: Author's Own Elaboration (2021)

Based on the results of research using Structural Equation Modeling (SEM) with Smart PLS (Partial Least Square) software, where there are 2 PLS models, namely the outer model and the inner model. External model is often also called (external relationship model or measurement model) specifies the relationship between the studied variable and its indicators (Ghozali \& Latan, 2015). Meanwhile, the mental model is used to study the relationship between latent constructs.

In this study, the researcher used a reflective model where the indicator is a manifestation of the construct so that the direction of the current relationship is from construct to indicator. Changes to the construct will affect the indicator changes in the indicator will not affect the construct. In the reflective model, between indicators have interchangeability, so the relationship between indicators must be highly correlated (Yamin \& Kurniawan, 2011). Based on the SmartPLS estimation method, the path measurement model diagram is obtained in figure 3. 


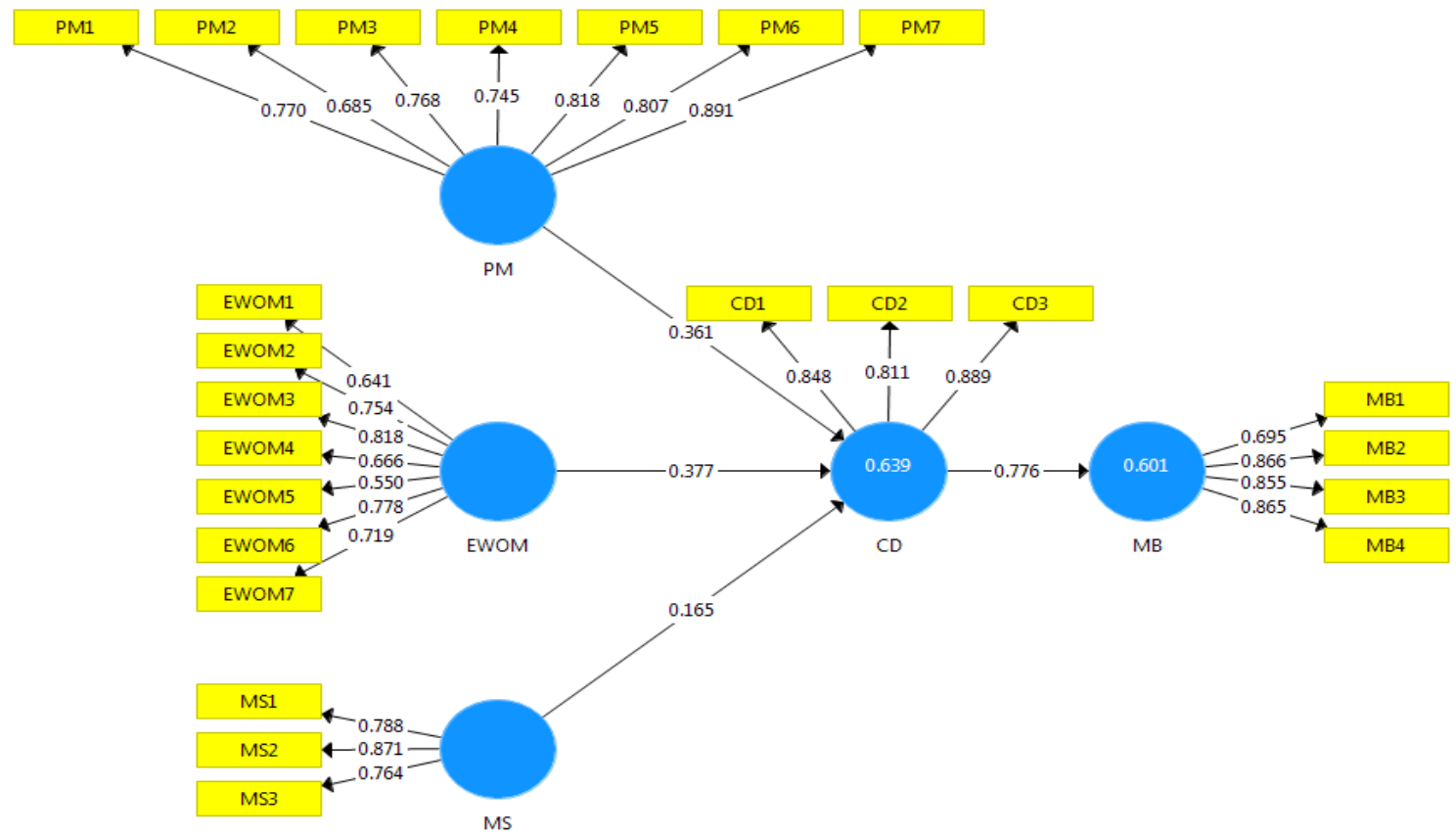

Figure 3. Outer Model Measure of Path Diagram

Source: Author's Own Elaboration (2021)

Through the path diagram above, it can be seen that the yellow box shows each indicator and the blue circle is a latent (indirect) variable. On each arrow there is a number, namely the value of the validity of each indicator and testing the reliability of the constructs of the variables studied. Indicators can be said to be valid if they have a factor weight greater than 0.5. The following shows the measurement of the validation and reliability models used in this study. The indicator is said to be valid if the AVE (Average Variance Extracted) value is above 0.5 so that it can be said that the measurement has met the criteria for convergent validity (Indrawati, 2015). The following table 2 are the test results using the Smart PLS software.

Table 2. Convergent Validity Result

\begin{tabular}{cccc}
\hline Variables & AVE & Cirtical Value & Model Evaluation \\
\hline Potential Market & 0,617 & & Valid \\
Electronik Word & 0,503 & & Valid \\
Of Mounth & & $>0,5$ & \\
Social Media Use & 0,654 & & Valid \\
Destination Image & 0,723 & & Valid \\
Visiting Interest & 0,678 & Valid \\
\hline
\end{tabular}

Source: Author's Own Elaboration (2021)

The table 2 shows that the three variables have a greater AVE value than the critical value, namely 0.5 . Thus, it can be concluded that all variables have met the requirements for convergent validity. Discriminant Validity can be seen by measuring the cross-loading factor by comparing AVE and the correlation between variables in a study. If the data shows that the correlation of each indicator's construct has a greater value than the value of the other constructs, then the variable has a high cross loading factor. The following table 3 is the result of the cross-loading factor using SmartPLS. 
Table 3. Discriminant Validity (Cross Loading Factor)

\begin{tabular}{rccccc}
\hline Indicators & $\begin{array}{c}\text { Potential } \\
\text { Market }\end{array}$ & $\begin{array}{c}\text { Electronic Word } \\
\text { Of Mounth }\end{array}$ & $\begin{array}{c}\text { Social Media } \\
\text { Use }\end{array}$ & $\begin{array}{c}\text { Destination } \\
\text { Image }\end{array}$ & $\begin{array}{c}\text { Visiting } \\
\text { Interest }\end{array}$ \\
\hline PMI & 0,589 & 0,502 & 0,603 & 0,429 & 0,770 \\
PM2 & 0,450 & 0,500 & 0,471 & 0,409 & 0,685 \\
PM3 & 0,607 & 0,590 & 0,549 & 0,306 & 0,768 \\
PM4 & 0,580 & 0,602 & 0,585 & 0,563 & 0,745 \\
PM5 & 0,613 & 0,683 & 0,666 & 0,398 & 0,818 \\
PM6 & 0,529 & 0,608 & 0,680 & 0,298 & 0,807 \\
PM7 & 0,638 & 0,671 & 0,700 & 0,500 & 0,891 \\
E-WOM1 & 0,391 & 0,641 & 0,496 & 0,364 & 0,465 \\
E-WOM2 & 0,535 & 0,754 & 0,568 & 0,315 & 0,528 \\
\hline E-WOM3 & 0,554 & 0,818 & 0,617 & 0,398 & 0,582 \\
E-WOM4 & 0,481 & 0,666 & 0,633 & 0,398 & 0,506 \\
\hline E-WOM5 & 0,247 & 0,550 & 0,415 & 0,302 & 0,479 \\
E-WOM6 & 0,635 & 0,778 & 0,638 & 0,578 & 0,553 \\
E-WOM7 & 0,688 & 0,719 & 0,638 & 0,402 & 0,639 \\
MSI & 0,395 & 0,341 & 0,414 & 0,788 & 0,386 \\
MS2 & 0,515 & 0,463 & 0,466 & 0,871 & 0,430 \\
\hline MS3 & 0,458 & 0,553 & 0,479 & 0,764 & 0,465 \\
\hline CD1 & 0,848 & 0,577 & 0,637 & 0,500 & 0,610 \\
CD2 & 0,811 & 0,555 & 0,569 & 0,541 & 0,502 \\
\hline CD3 & 0,889 & 0,744 & 0,753 & 0,429 & 0,735 \\
MB1 & 0,562 & 0,568 & 0,695 & 0,346 & 0,535 \\
\hline MB2 & 0,694 & 0,747 & 0,866 & 0,458 & 0,655 \\
MB3 & 0,639 & 0,689 & 0,855 & 0,533 & 0,707 \\
MB4 & 0,651 & 0,680 & 0,865 & 0,501 & 0,655 \\
\hline
\end{tabular}

Source: Author's Own Elaboration (2021)

The table 3 shows that all the constructs in the estimated model have met the criteria for discriminant validity. The condition is that the square root value of the AVE for each construct is greater than the value between the constructs, so it can be said that the indicators used in this study have met the requirements.

Reliability test is done to see the permanence of an instrument (measuring instrument) in measuring the same symptoms even though in different times. According to Sugiyono (2018) "Instrument reliability is an instrument that when used several times to measure the same object, it will produce the same data". Here are the results of the model reliability test:

Table 4. Reliability Test Result

\begin{tabular}{cccccc}
\hline Variabel & $\begin{array}{c}\text { Composite } \\
\text { Relability }\end{array}$ & $\begin{array}{c}\text { Critical } \\
\text { Value }\end{array}$ & $\begin{array}{c}\text { Cronbach's } \\
\text { Alpha }\end{array}$ & $\begin{array}{c}\text { Critical } \\
\text { Value }\end{array}$ & $\begin{array}{c}\text { Model } \\
\text { Evaluatio } \\
\mathbf{n}\end{array}$ \\
\hline $\begin{array}{c}\text { Market Potential } \\
\text { Electronic Word Of Mouth } \\
\text { (E-WOM) }\end{array}$ & 0,918 & 0,895 & Reliable \\
$\begin{array}{c}\text { Social Media Use } \\
\text { Destination Image }\end{array}$ & 0,850 & $>0,7$ & 0,835 & Reliable \\
Visiting Interest & 0,887 & & 0,735 & $>0,6$ & Reliable \\
\hline
\end{tabular}

Source: Author's Own Elaboration (2021) 
In the table 4, the composite reliability and cronbach's alpha values for each variable have more than 0.7 and 0.6, respectively. Therefore, it can be said that the data has high reliability. In this stage, the inner model describes the relationship between latent variables based on the Substantive theory (Noor, 2014). The structural model is formed based on the theory and results of empirical research (previous research). The following figure 4 is a path diagram of the inner research model.

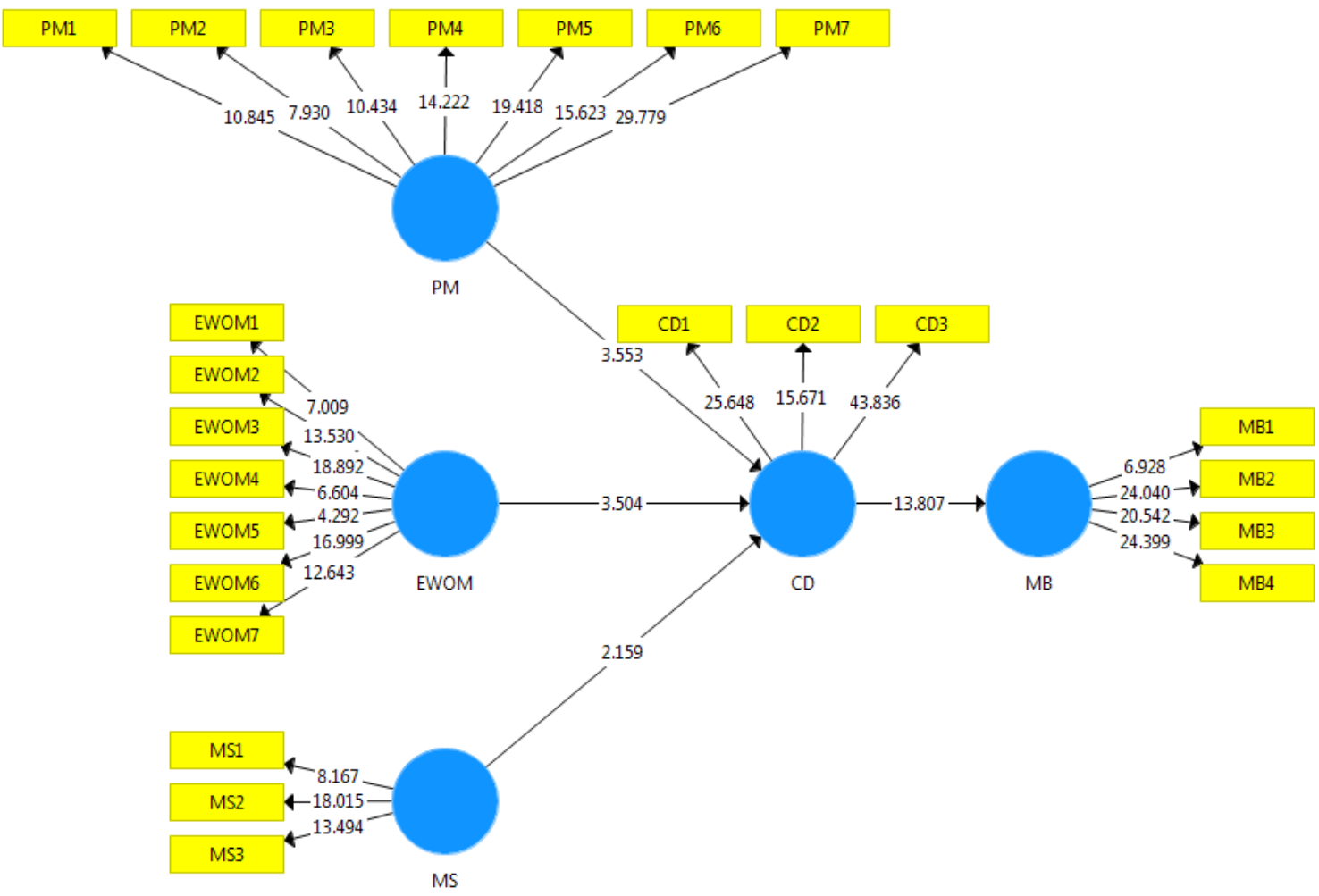

Figure 4. Inner Model Measure / Path Diagram (Bootstraping)

Source: Author's Own Elaboration (2021)

The significant assessment of the prediction model in structural model testing can be seen from the $t$-statistic value between the independent variable on the dependent variable and the intervening variable in the path diagram. Evaluation of structural measurements. The value of R-Square is the coefficient of determination on endogenous constructs. The higher the R-Square value, the better the prediction model of the proposed research model.

Table 5. R-Square Value

\begin{tabular}{cc}
\hline Variabel & R-Square \\
\hline Destination Image & 0,639 \\
Visiting Interest & 0,601 \\
\hline Source: Author's Own Elaboration $(2021)$
\end{tabular}

Based on table 5, it can be seen that the R-Square value on the destination image variable is 0.639 and for the visiting interest variable is 0.601 . The R-Square value for the destination image variable is $63.9 \%$, which means that the destination image variable can be explained by the visiting interest variable and the remaining $22.5 \%$ is influenced by other variables that are not explained in this study. Then after knowing the value of the R-square, it is necessary to measure it with $Q$-square which aims to measure how well the observed value generated by the model and also its parameter estimation using $Q$-square. A model has predictive relevance when the $Q$-square $>0$ (zero/null), while the value of $Q$-square< 
0 (zero/null) then the model lacks predictive relevance which can be calculated with the following formula:

$$
Q^{2}=1-(1-R \quad)(1-R \quad) \ldots(1-R \quad)=1-(1-0,639)(1-0,0,601)=0,789
$$

Predictive relevance is $0,789>0$ (zero/null1), then the model has a relevant predictive value. The table 6 shows the hypothesis result:

Tabel 6. Path Coefficience

\begin{tabular}{|c|c|c|c|c|c|}
\hline Variable & $\begin{array}{c}\text { Original } \\
\text { Sample } \\
(\mathrm{O}) \\
\end{array}$ & $\begin{array}{l}\text { Sample } \\
\text { Mean } \\
\text { (M) }\end{array}$ & $\begin{array}{c}\text { Standard } \\
\text { Deviation } \\
\text { (STDEV) }\end{array}$ & $\begin{array}{c}\text { T Statistics } \\
(|\mathrm{O} / \mathrm{STDEV}|)\end{array}$ & P Values \\
\hline $\begin{array}{l}\text { Destination Image - } \\
>\text { Visiting Interest }\end{array}$ & 0,776 & 0,774 & 0,056 & 13,807 & 0,000 \\
\hline $\begin{array}{l}\text { Electronic Word Of } \\
\text { Mouth -> } \\
\text { Destination Image }\end{array}$ & 0,377 & 0,383 & 0,107 & 3,504 & 0,000 \\
\hline $\begin{array}{l}\text { Social Media Use -> } \\
\text { Destination Image }\end{array}$ & 0,165 & 0,164 & 0,076 & 2,159 & 0,031 \\
\hline $\begin{array}{l}\text { Potential Market -> } \\
\text { Destination Image }\end{array}$ & 0,361 & 0,353 & 0,102 & 3,553 & 0,000 \\
\hline
\end{tabular}

Source: Author's Own Elaboration (2021)

We found that the $\mathrm{T}$ value is 13.807> 1.96 which shows a significant meaning, with the original sample value of 0.776 which means that the destination image has a positive and significant effect on visiting interest. The direction of the positive relationship shows that the more the image of the destination increases, it will be followed by increased interest in visiting. Thus, it is very important to pay attention to the extent of the destination image that is owned by the Sebalang mangrove forest tourism park. In tourist activities, visitors (tourists) must be considered like a guest visiting a Muslim family home (destination). In Islam, every guest must be respected, among others by being treated to proper and appropriate treats, complemented by excellent service by the host. Thus, that the guest can feel at home and happy, supported by the atmosphere and conditions which are clean and friendly. There is also a requirement in facilities such as prayer room (mushalla), room for wudhu and clean restroom. A positive image will emerge and gives an ideal syar'i family destination (Pradana et al., 2020). The same thing was stated by Timurti and Nugraha (2018), based on the results of their research it showed that there was a positive relationship between the image of the destination and the interest in visiting again, so the image of the destination was getting higher. from the destination, the more interest to visit again.

The effect of the Electronic Word of Mouth on the image of halal tourism destinations, it is obtained that the $T$ value of 3.504> 1.96 shows a significant meaning, with the original sample value of 0.377 which means that the Electronic Word of Mouth (E-WOM) has a positive and significant effect on the image of the destination. The direction of the positive relationship shows that the increasing E-WOM, it will be followed by an increase in the image of halal tourist destinations. The same thing was also stated by Rofiah (2020) who stated that the Electronic Word of Mouth (E-WOM) can improve the image of the destination for visitors to tourist attractions. Suwarduki et al (2016), stated that the Electronic Word of Mouth (E-WOM) has a significant effect on the image of the destination.

The influence of social media on the image of halal tourist destinations, it is obtained that the $\mathrm{T}$ value is 2.159> 1.96 which shows a significant meaning, with the original sample value of 0.165 which means that social media has a positive and significant effect on the image of halal tourist destinations. The direction of the positive relationship shows that the increasing promotion carried out on social media can improve the image of halal tourist destinations for visitors to the Sebalang mangrove forest tourism park. Isman et al (2020), stated that social media has a significant effect on the image of tourist 
destination. Potential future tourists are attracted by an effective promotion and marketing plan, so the use of social media is the easiest way of marketing to keep up with the development of information technology (Nugraha, 2018). Market characteristics and behavior determine the success of market communication (Jamiat et al., 2020).

The influence of the market potential on the Image of the Destination, obtained a T-value of 3.553> 1.96 , with the original sample value of 0.361 which means that the original sample has a positive and significant effect on the image of halal tourism destinations. The direction of the positive relationship shows that the increasing potential market provided by the Sebalang mangrove forest tourism park can improve the image of halal tourist destinations for visitors to the mangrove forest tourism park, Sebalang.

Table 7. Indirect Effects

\begin{tabular}{lccccc}
\hline \multicolumn{1}{c}{ Variables } & $\begin{array}{c}\text { Original } \\
\text { Sampel } \\
(\mathbf{O})\end{array}$ & $\begin{array}{c}\text { Sampel } \\
\text { Mean } \\
(\mathbf{M})\end{array}$ & $\begin{array}{c}\text { Standard } \\
\text { Deviation } \\
\text { (STDEV) }\end{array}$ & $\begin{array}{c}\text { T Statistics } \\
\text { (|O/STDEVI) }\end{array}$ & P Values \\
\hline $\begin{array}{l}\text { e-WOM -> Visiting } \\
\text { Interest }\end{array}$ & 0,292 & 0,296 & 0,082 & 3,568 & 0,000 \\
$\begin{array}{l}\text { Social Media Use -> } \\
\text { Visit Intention }\end{array}$ & 0,128 & 0,128 & 0,061 & 2,109 & 0,035 \\
$\begin{array}{l}\text { Potential Market } \rightarrow \\
\text { Visiting Interest }\end{array}$ & 0,280 & 0,276 & 0,089 & 3,146 & 0,002 \\
\hline
\end{tabular}

Source: Author's Own Elaboration (2021)

Based on table 7 above, an explanation of the hypothesis can be obtained is that the effect of Electronic Word of Mounth on Visiting Interest through the Image of Halal tourist destinations, it is obtained that the $T$ value of 3.568> 1.96 shows a significant meaning, with the original sample value of 0.292 which means that the Electronic Word of Mounth (E-WOM) has a positive effect and significant to Visiting Interest through the Destination Image variable. The direction of the positive relationship shows that the increasing E-WOM, it will be followed by an increase in visiting interest by increasing the image of halal tourism destinations first. The results of this study are in line with previous research conducted by Suwarduki et al (2016) which states that the Electronic Word of Mounth (E-WOM) has a significant effect on Visiting Interest through Destination Imaging. The influence of Social Media on Visiting Interest through the image of halal tourist destinations, the T value is $2.109>1.96$ which shows a significant meaning, with the original sample value of 0.128 which means that Social Media has a positive and significant effect on Visiting Interest through the variable Image of halal tourist destinations.

The direction of the positive relationship shows that the increasing promotion carried out on Social Media, it can increase Visiting Interest by increasing the image of halal tourist destinations first. Sholikha and Sunarti (2019), stated that social media has a very high effect on visiting interest. Social media involves the use of web technologies to transform one-way communication into an interactive online dialogue. A key of component of social media is the creation and exchange of user generated conten (Dixon, 2012). Building a good "image", especially the image of halal tourism products such as tourism destinations is a must and important (Pradana et al., 2020). With the creation of a positive image of tourist destinations, they will be able to attract more consumers, spend more money, meet their needs and wants in a sustainable manner and maybe they will come again to visit or buy products (goods and services), and this all cannot be separated from the role of social media that is able to generate interest in returning to visit (Nugraha, 2018).

The influence of Potential Market on Visiting Interest through the Destination Image variable, obtained a $T$ value of 3.146>1.96, with a path coefficients value of 0.280 , which means that the potential market has a positive and significant effect on Visiting Interest through the image of halal tourism destinations this result supports the findings by Nasrullah (2016). The direction of a positive 
relationship shows that the increasing Potential Market provided by the mangrove forest tourism park Sebalang can increase Visiting Interest by improving the image of a halal tourist destination first. Potential market is the overall market size for a product at any given time. Potential market is usually measured in terms of sales value or sales volume. In a business context, potential market is part of a marketing strategy. Marketing strategy is defined as: "a plan by a company to differentiate itself positively from its competitors, using its relative strengths to satisfy customer needs in a given environment (Lee, 2011; Nugraha, 2018). The potential market of a tourist destination can provide satisfaction to its visitors if the tourist destination is able to build tourist destination positioning, the success of a position is largely determined by the ability to determine the target market in accordance with the product and potential of a tourist destination. As stated by Jamiat et al. (2020), building an "image" of both the image of manufactured products and the image of tourism products such as tourism destinations is a must and important. So a good market potential will affect the image of a tourist destination, and in the end will increase the interest of tourists to visit.

\section{Conclusion}

Based on the results of the research that has been done, it can be concluded that the role of the image of halal tourism destinations on visiting interest has a big influence, which is $77.6 \%$, this proves that the image of halal tourist destinations can affect the interest in visiting tourists to mangrove forests in Sebalang Hamlet. This of course cannot be separated from the role of the local government which continues to make improvements in the tourism sector in Sembalang Hamlet. Where the image of halal tourist destinations will not develop properly if it is not supported by E-WOM, social media, and market potential which are carried out continuously. But in reality, based on the results of the survey at the end of mangrove forest tourists in Sebalang Hamlet, it is still very low, this can be proven based on the research results that the effect of the image of halal tourist destinations on E-WOM is still low, namely $37.7 \%$, then the influence of the image of tourist destinations halal for social media is still low at $16.5 \%$, and the influence of the image of halal tourist destinations on market potential is still low at $36.1 \%$.

We believe that this research contribute in opening new perspective in te use of E-WOM in tourism. The concept of E-WOM has been used in marketing for almost two decades, but it has rarely been found in tourism, especially halal tourism (Maharani et al., 2016). Taking social media use into account also drives this study toward new direction, especially in the era of technology which defines future direction. of tourism sector.

Practically, we believe that the results of this study are the need for good cooperation between the local government, the community and all parties related to the surrounding environment to be able to work together to increase halal tourism in Sebalang Hamlet, Tarahan Selatan Village. Lampung Regency, and actively uses social media to increase the number of visits by local and foreign tourists. Last, we hope that the next researcher will develop the results of this study by considering other variables outside the variables that have been used in this study.

\section{References}

Aaker, David, A. (2012). Manajemen Ekuitas Merek: Memanfaatkan Nilai dari Suatu Merek. Jakarta: Mitra Utama. Annafik, A. F., \& Rahardjo, M. (2012). Analisis Pengaruh Kualitas Produk, Harga, Dan Daya Tarik Iklan Terhadap Minat Beli Sepeda Motor Yamaha (Studi kasus pada konsumen Yamaha SS Cabang Kedungmundu Semarang). Diponegoro Journal of Management, 1(4), 274-281.

Croy, G. (2014). Destination image evaluation: Part II. Eclipse: The Periodic Publication From Moonshine Travel Marketing for Destination Marketers, 10, 1-12.

Dixon, B. (2012). Social media for school leaders: A comprehensive guide to getting the most out of Facebook, Twitter, and other essential web tools. New Jersey: John Wiley \& Sons.

Fatkurrohman. (2017). Developing Yogyakarta's Halal Tourism Potential for Strengthening Islamic Economy in Indonesia. Afkaruna: Indonesian Interdisciplinary Journal of Islamic Studies, 13(1), 1-16.

Ghozali, I., \& Latan, H. (2015). Partial Least Squares, Konsep, Teknik Dan Aplikasi Menggunakan Program Smartpls3.0. Semarang: Badan Penerbit Universitas Diponegoro. 
Imran, A., \& Efendi, I. (2016). Inventarisasi mangrove di pesisir Pantai Cemara Lombok Barat. JUPE: Jurnal Pendidikan Mandala, 1(1), 105-112.

Indrawati. (2015). Metode Penelitian Manajemen dan Bisnis Konvergensi Teknologi Komunikasi dan Informasi. Bandung: PT Refika Aditama.

Isman, I., Patalo, R. G., \& Pratama, D. E. (2020). Pengaruh Sosial Media Marketing, Ekuitas Merek, Dan Citra Destinasi Terhadap Minat Berkunjung Ke Tempat Wisata. Jurnal Studi Manajemen Dan Bisnis, 7(1), 30-36.

Jamiat, N., Hidayat, A. M., Pradana, M., \& Bastio, B. S. (2020). The Influence Of Brand Image On The Decision Of Buying Converse Shoes In Students In Bandung City, Indonesia. International Journal of Advanced Research in Engineering and Technology (IJARET), 11(12), .438-445. https://doi.org/10.34218/IJARET.11.12.2020.047

Kotler, P., \& Keller, K. L. (2016). Marketing Manegement (15th ed.). London: Pearson Education.

Kotler, Philip, \& Amstrong, G. (2016). Pemasaran Jilid 1 (13th ed.). Jakarta: Erlangga.

Lee, T. H. (2011). A Structure Model toExamine How Destination Image, Attitude, and Motivation Affect the Future Behavior of Tourist. Leisure Science, 31, 215-236.

Madiawati, P. N., \& Pradana, M. (2016). Celebrity and halal certificates factors influence on customers' buying interest. Актуальні Проблеми Економіки, 3, 109-116.

Maharani, B., Pradana, M., \& Wijaksana, T. I. (2016). Instagram electronic word of mouth's effect towards purchasing decision arromanis corner store, bandung, Indonesia. International Journal of Scientific Engineering and Applied Science (IJSEAS), 2(6), 145-150.

Nasrullah, R. (2016). Media Sosial Perspektif Komunikasi, Budaya, dan sosioteknologi. Bandung: Rosdakarya.

Noor, J. (2014). Metodologi Penelitian. Jakarta: Kencana Prenada Media Group.

Nugraha, Y. M. (2018). Analisis Potensi Promosi Pariwisata Halal Melalui E-Marketing di Kepulauan Riau. Jurnal Penelitian Dan Karya Ilmiah Lembaga Penelitian Universitas Trisakti, 3(2), 63-68.

Pradana, M., Huertas-García, R., \& Marimon, F. (2020). Muslim tourists' purchase intention of halal food in Spain. Current Issues in Tourism, 1-5. https://doi.org/10.1080/13683500.2020.1797647

Rofiah, C. (2020). Pengaruh Electronic Word Of Mouth Terhadap Keputusan Berkunjung Dimediasi Oleh Citra Destinasi. Jurnal Riset Manajemen Dan Bisnis Dewantara (JMD), 3(1), 32-39.

Sholikha, E. A., \& Sunarti, S. (2019). Pengaruh Media Sosial terhadap Minat Berkunjung Followers (Survei pada followers akun Instagram@ batuflowergarden. cobanrais). Jurnal Administrasi Bisnis, 70(1), 11-18.

Sugiyono. (2018). Metode Penelitian Kuantitatif Kualitatif dan Kombinasi (Mixed Methods). Bandung: Alfabeta.

Suwarduki, P. R., Yulianto, E., \& Mawardi, M. K. (2016). Pengaruh electronic word of mouth terhadap citra destinasi serta dampaknya pada minat dan keputusan berkunjung (survei pada followers aktif akun instagram indtravel yang telah mengunjungi destinasi wisata di Indonesia). Jurnal Administrasi Bisnis, 37(2), 1-10.

Yamin, S., \& Kurniawan, H. (2011). Generasi Baru Mengolah Data Penelitian dengan Partial Least Square Path Modeling : Aplikasi dengan Software XLSTAT, SmartPLS, dan Visual PLS. Jakarta: Salemba Infotek.

(C) 2021 by the authors. Submitted for possible open access publication under the terms and conditions of the Creative Commons Attribution (CC BY SA) license (https://creativecommons.org/licenses/by-sa/3.0/). 
This page is intentionally left blank 